\title{
The effects of transcutaneous electrical nerve stimulation on tissue repair: A literature review
}

\author{
Aline Fernanda Perez Machado PT, Eduardo Ferreira Santana PT, \\ Pascale Mutti Tacani PT MSc, Richard Eloin Liebano PT PhD
}

\begin{abstract}
AFP Machado, EF Santana, PM Tacani, RE Liebano. The effects of transcutaneous electrical nerve stimulation on tissue repair: A literature review. Can J Plast Surg 2012;20(4):237-240.
\end{abstract}

BACKGROUND: Transcutaneous electrical nerve stimulation (TENS) consists of a generic application of low-frequency, pulsed electrical currents transmitted by electrodes through the skin surface. It is a therapeutic modality that is nonpharmacological, noninvasive, inexpensive, easy to use and widely applied in clinical practice.

OBJECTIVE: To narratively review the scientific evidence of the effects of TENS on tissue repair with respect to wound healing, skin flap viability and tendinous repair.

METHODS: The study was conducted using the MEDLINE, Lilacs and Scielo databases, without limit to the period of publication, and was completed in November 2011. Inclusion criteria were randomized or nonrandomized, controlled or noncontrolled clinical trials, and experimental trials involving rats subjected to TENS for tissue repair.

RESULTS: Thirty articles on tissue repair were found and, among these, 14 reported on wound healing, 14 reported on skin flaps and two analyzed tedinous repair.

DISCUSSION: It was suggested that TENS stimulates skin wound healing and tendon repair, as well as the viability of random skin flaps. Such effects may be due to the release of substance $\mathrm{P}$ and calcitonin gene-related peptide, which would increase blood flow and, consequently, hasten the events leading to tissue repair.

CONCLUSIONS: Based on the scientific evidence regarding the effects of TENS on tissue repair, the findings of the present literature review were inconclusive because data from the randomized controlled clinical trials were insufficient to confirm such effects.

Key Words: Achilles tendon; Literature review; Physical therapy modalities; Transcutaneous electric nerve stimulation; Skin flaps; Wound healing

Transcutaneous electrical nerve stimulation (TENS) consists of a 1 generic application of low-frequency, pulsed electrical currents transmitted by electrodes through the skin surface (1-6) to stimulate the peripheral nerves to produce various physiological effects (7).

It is a nonpharmacological, noninvasive, inexpensive, easy to use and widely applied therapeutic modality used in clinical practice $(1-4,8)$. The common electrical pulses emitted by TENS devices are described as monophasic rectangular, balanced asymmetrical biphasic rectangular, or symmetrical biphasic rectangular; the biphasic pulses are the most commonly used (9-12).

The first TENS units were developed (6) and soon became popular after the publication of the gate control theory of pain postulated by Melzack and Wall in 1965 (13). According to this theory, the activation of large-diameter afferent fibres (A-beta fibres) activates local inhibitory mechanisms in the dorsal horn of the spinal cord causing the presynaptic inhibition of nociceptive afferent fibres (A-delta and C) $(2,6,7,14,15)$.

Since 1965 , TENS has become known worldwide and is also considered to be one of the most common therapeutic resources used in clinical practice for the relief of chronic and acute pain. However, in recent decades, some authors have observed that, in addition to its

\section{Les effets de la stimulation nerveuse électrique transcutanée sur la réparation tissulaire : une analyse bibliographique}

HISTORIQUE : La stimulation nerveuse électrique transcutanée (SNET) désigne l'application générique de courants électriques pulsés à faible fréquence transmis à travers la surface de la peau par des électrodes. C'est une modalité thérapeutique non pharmacologique, non effractive, peu coûteuse, facile à utiliser et largement appliquée en pratique clinique.

OBJECTIF : Procéder à l'analyse narrative des données scientifiques probantes sur les effets de la SNET sur la réparation tissulaire en matière de guérison des plaies, de viabilité du lambeau cutané et de réparation tendineuse.

MÉTHODOLOGIE : L'étude a été conçue à l'aide des bases de données MEDLINE, Lilacs et Scielo, sans limite pour la période de publication, et a pris fin en novembre 2011. Les critères d'inclusion étaient des essais cliniques aléatoires ou non et contrôlés ou non et des essais expérimentaux touchant des rats soumis à la SNET pour réparer les tissus.

RÉSULTATS : Les chercheurs ont trouvé 30 articles sur la réparation tissulaire et, de ce nombre, 14 traitaient de la guérison des plaies, 14 des lambeaux cutanés et deux des réparations tendineuses.

EXPOSÉ : Il a été postulé que la SNET stimule la guérison des plaies cutanées et la réparation des tendons, de même que la viabilité des lambeaux cutanés pris au hasard. Cet effet serait causé par la libération de la substance $P$ et du peptide lié au gène calcitonine, qui accroîtrait le débit sanguin et, par conséquent, accélérerait les événements responsables de la réparation tissulaire.

CONCLUSIONS : D'après les données scientifiques probantes sur les effets de la SNET sur la réparation tissulaire, les résultats de la présente analyse bibliographique n'étaient pas concluants puisque les données des essais cliniques aléatoires et contrôlés n'étaient pas suffisantes pour confirmer ces effets.

analgesic effects, TENS can alter skin temperature and increase blood flow $(2,7,14,15)$. This observation led many studies to focus on the effect of TENS on the peripheral vascular system, showing increases in blood flow (16) and, therefore, possibly facilitating tissue repair.

The purpose of the present narrative review is to describe the scientific evidence regarding the effects of TENS on tissue repair with respect to wound healing, the viability of skin flaps and tendinous repair.

\section{METHODS}

The review was based on indexed scientific articles found in the MEDLINE, Lilacs and Scielo databases without limit to the period of publication. The present study was completed in November 2011.

The search strategy was performed using the the following medical subject heading terms: "transcutaneous electric nerve stimulation", "wound healing", "Achilles tendon" and "surgical flaps". These headings were crossed with the Boolean operator "AND".

The inclusion criteria were randomized or nonrandomized, controlled or noncontrolled clinical trials, and experimental trials involving rats subjected to TENS for tissue repair.

Research articles that discussed the use of electrical currents but did not characterize TENS were excluded.

Physical Therapy Department, São Paulo City University, São Paulo, Brazil

Correspondence: Ms Aline FP Machado, Physical Therapy Department, São Paulo City University, Cesário Galeno Street, 448/475, Tatuapé

03071-000, São Paulo, Brazil. Telephone 55-11-2178-1240, fax 55-11-2178-1355, e-mail lifpm@yahoo.com.br 


\section{RESULTS}

Thirty articles on tissue repair were found, 14 of which reported the effects of TENS in wound healing, 14 on skin flap survival and two on tendinous repair.

\section{DISCUSSION}

\section{Skin wound healing}

At the top of the pyramid of scientific evidence are systematic reviews and meta-analyses, which comprise the most valid, reliable studies that produce knowledge. These are the randomized controlled clinical trials that involve thousands of patients and limited data collection known as 'mega trials' (17-19). In contrast, at the base of the pyramid are experimental studies involving a clinically or surgically induced model (1719). These models offer an understanding of the various processes that may occur in the target tissue, providing microscopic analyses that are not always possible to perform in human subjects (17).

Surgically induced models have been used to assess the effects of electrophysical resources in tissue repair (3,9-11,20-28). However, among the 14 articles $(23,29-39)$ found reporting on the use of TENS in wound healing, only one described an experimental study involving rats (23). This fact makes it difficult to know what cellular events are responsible for the results obtained in tissue. Therefore, the importance of initiating research in experimental models should be emphasized because these are the primary studies required to analyze immunohistological variables in tissue.

Some of the effects of TENS on various types of skin lesions include the repair of diabetic ulcers $(29,33-35,37)$, chronic leprous ulcers (32), pressure ulcers caused by spinal cord injuries $(36,40)$, chronic venous ulcers (39) and in stump healing after major lower limb amputation (31).

The main adjusted parameters were frequency and current amplitude, and duration of application. The current modulation ranged between a low frequency of $2 \mathrm{~Hz}(29,31,32,34,39)$ and high frequency of between $80 \mathrm{~Hz}(33)$ and $100 \mathrm{~Hz}(38)$. The current amplitude was adjusted between $0 \mathrm{~mA}$ and $70 \mathrm{~mA}$, with muscle contraction in patients with diabetic neuropathy (37-39); from $10 \mathrm{~mA}$ to $15 \mathrm{~mA}$ in intact skin and blister wounds in healthy volunteers (38); and ranging from $20 \mathrm{~mA}$ to $45 \mathrm{~mA}$ for the healing of chronic venous ulcers (39). Regarding the duration of application, there was a large discrepancy: in the clinical studies, duration ranged from $20 \mathrm{~min}(33,34)$ to $2 \mathrm{~h}(40)$, whereas the experimental studies used a duration of only $1 \mathrm{~min}$ (23).

All clinical studies showed significant differences in wound healing using TENS, with reductions in wound sizes of up to $60 \%$ compared with the control group (35), increases of $35 \%$ in blood flow in ulcers and $15 \%$ in the intact skin surrounding the ulcer (39). In addition, TENS provided faster healing following foot amputation, decreased the number of re-amputation cases in individuals with diabetes and relieved pain during stimulation (31).

Khalil and Merhi (23) performed the only experimental study on TENS and wound healing. The authors evaluated sensitive nerve function using low-frequency TENS $(5 \mathrm{~Hz})$ for $1 \mathrm{~min}$ in young and old rats, applying it to the sciatic nerve to accelerate tissue repair. It was observed that the use of low-frequency TENS increased vascular response and was effective in skin wound healing, not only in young rats but also in the older rats, in seven days. This single animal study suggests the promise of TENS for skin wound healing, and that it may be the result of an increase in blood flow. Of course, these data cannot be extrapolated to humans.

However, disagreements in the literature remain with regard to the increase in blood flow and skin temperature. Some studies have shown that TENS significantly increases skin temperature with low- (2 $\mathrm{Hz}$ to $4 \mathrm{~Hz})(14,41,42)$ and high-frequency $(75 \mathrm{~Hz}$ to $100 \mathrm{~Hz})$ TENS $(43,44)$, and in local blood flow with low $(41,42,45-47)$ and high frequencies $(16,44)$. On the other hand, other authors did not observe any significant increase of blood flow (48) and skin temperature $(16,46)$ with the use of TENS.

According to the findings, greater effectiveness of low-frequency TENS was observed $(14,38,45)$ due to an increase of $40 \%$ and $12 \%$ of local blood flow in low $(2 \mathrm{~Hz})$ and high $(100 \mathrm{~Hz})$ frequencies, respectively (38). However, to date, this is the only study that compared the effects of different frequencies of TENS, revealing the lack of consensus in the literature on which one would present more satisfactory results in increasing blood flow. Additional studies are necessary to compare the effects of each TENS frequency on tissues.

In older rats, Khalil et al (24) reported that the neurogenic vascular response to release specific sensory neuropeptides depends on the type of frequency applied (ie, low-frequency TENS [ $5 \mathrm{~Hz}$ ] releases calcitonin gene-related peptide [CGRP] and, in high-frequency [15 Hz], substance $\mathrm{P}$ [SP]). In turn, the SP and CGRP neuropeptides have a strong vasodilatory action and promote beneficial effects on wound healing in soft tissues (49). Thus, it is suggested that vasodilation produced by TENS can be related to the local release of neuropeptides.

Current amplitude also has some influence on blood flow because when the amplitude exceeded $25 \%$ of the motor threshold, there was a transient increase in local blood flow $(16,47)$; however, when low intensity was applied, it produced little or no increase in blood flow.

An increase in skin temperature has also been associated with analgesia when TENS was used in patients who experienced chronic pain in the extremities. Pain relief was observed in the stimulated and contralateral limb when there was an increase in skin temperature, whereas the pain persisted in individuals whose skin temperature did not change. The analgesic effect was possibly the result of reduced sympathetic activity, which induces vasodilation and relieves pain (43).

Therefore, it is suggested that TENS increases blood flow, thereby stimulating the healing of various types of wounds. However, there is no consensus regarding its influence on the increase in skin temperature. Further investigation is necessary to associate increased skin temperature with the other effects of TENS such as analgesia, increased blood flow, tissue repair and sensory response. In addition, the combination of TENS parameters - frequency and amplitude should be verified due to the probable joint action on the increase of blood flow and, consequently, improvement in tissue repair.

\section{Viability of skin flaps}

Given that TENS may have beneficial effects on wound healing, its use can also minimize ischemic complications in skin flaps, which fail in treatments in the scope of plastic surgery (3).

The effect of TENS on the viability of skin flaps has been more extensively studied than its effects on wound healing because most studies on the viability of skin flaps are experimental and have used rat models. Using histological and histochemical methods to examine cellular responses, a total of nine experimental studies on TENS application in skin flaps were found $(1,3,9,10,22,25-28)$. Only five studies investigating the survival of skin flaps using macroscopic analysis of necrosis area and other postoperative signs and symptoms in human subjects were found $(11,15,21,33,50)$.

Regarding TENS parameters, frequencies ranged between low $(2 \mathrm{~Hz})$ $(3,9,22)$ and high $(70 \mathrm{~Hz}[15], 80 \mathrm{~Hz}[1,9,10,20,22,25,27]$ and $90 \mathrm{~Hz}$ $[11,21])$. The shortest application time was $1 \mathrm{~h}(1,3,9,15,25,26)$ and the longest was $2 \mathrm{~h}(11,21)$.

With regard to the current amplitude used in experimental studies, TENS achieved better results when it was applied with high amplitude ranging between $15 \mathrm{~mA}(1,3,27)$ and $20 \mathrm{~mA}(9)$; however, in humans, patient sensitivity was used to determine the level of stimulation (11), with an amplitude of $2 \mathrm{~mA}$ demonstrating beneficial effects on the viability of postmastectomy skin flaps (15).

It was not possible to determine the number of TENS applications, which ranged from approximately two times per day in the postoperative $(\mathrm{PO})$ period (11) to once a day for five days starting on the first PO (15) day or until there was a significant decrease in the signs of ischemia (21).

The literature was unanimous in reporting statistically significant improvement in the viability of random skin flaps in rats as well as in humans. However, studies that used high-frequency TENS obtained more satisfactory results compared with the low-frequency TENS (22) and control groups (15). 
Significant increases in blood flow in skin flaps were demonstrated by using laser Doppler flowmetry with the application of TENS $(9-11,20)$. This increase can last for approximately $10 \mathrm{~h}(11)$ and reduced ischemia, which may cause necrosis of surgical flaps. In addition, the significant decrease in necrosis and ecchymosis demonstrated by Atalay and Yilmaz (15) supports the action of TENS in the microcirculation, probably not only by its vasodilatatory action with increased skin-blood irrigation, but also with increased venous and lymphatic flow, with decreases in stasis, swelling and bruising. In contrast, only Jenbeck and Daslgaard (50) observed that the increase in blood flow was more effective in three patients with ischemic flaps receiving intravenous CGRP compared with individuals who were subjected to TENS.

TENS can be used as an alternative to drug therapy in the PO care of plastic surgery patients because it does not produce systemic effects, but only rare cases of skin allergies caused by the self-adhesive electrodes $(20,21)$. TENS also produces similar effects by decreasing flap necrosis $(3,15,25,27,28)$ and can be safely applied $(15)$.

\section{Tendinous repair}

The use of TENS in tendon healing is a new field of exploration. Recent research has investigated the effects of burst TENS on Achilles tendon healing.

Two studies $(49,51)$ investigated TENS in 20 patients who acquired sports-related Achilles tendon injuries. Treatment with burst TENS was performed five days per week during the second and third weeks of PO care. The following parameters were used: burst TENS with a pulse train duration of $300 \mathrm{~ms}$, internal frequency of $100 \mathrm{~Hz}$, burst frequency of $2 \mathrm{~Hz}$ and variable amplitude according to the patient's tolerance, without visible muscular contractions.

Among the 20 patients, only 18 completed the study, nine underwent TENS and nine received simulated treatment. It was found that the group who received burst TENS treatment experienced effective proliferation of fibroblasts (49), and production, maturation and organization of collagen fibres (51). Therefore, both studies suggest that TENS can have a positive influence on Achilles tendon healing in males due to the release of CGRP and SP sensory neuropeptides. Achilles tendon rupture has been described for many years (52) as a serious injury and one of the most common among the musculotendinous lesions (53). However, it is interesting to note that these findings are restricted only to healing in the Achilles tendon because of its superficial location and by the fact that it can be easily stimulated by the current. Emphasis should be given to studies that address the healing of deeper tendons so that TENS could be useful in healing such tissues.

\section{CONCLUSION}

It is suggested that TENS stimulates skin wound healing and tendon repair, as well as the viability of random skin flaps. Such effects may be due to the release of SP and CGRP, which would increase blood flow and, consequently, hasten the events of tissue repair. However, the findings of the present literature review, based on the scientific evidence on the effects of TENS on tissue repair, are inconclusive because data from the randomized controlled clinical trials were insufficient to confirm such effects.

\section{REFERENCES}

1. Liebano RE, Ferreira LM, Sabino Neto M. Experimental model for transcutaneous electrical nerve stimulation on ischemic random skin flap in rats. Acta Cir Bras 2003;18:54-9.

2. Buonocore M, Camuzzini N. Increase of the threshold during and after high-frequency transcutaneous peripheral nerve stimulation in a group of normal subjects. EURA 2007;47:155-60.

3. Liebano RE, Abla LEF, Ferreira LM. Effect of low-frequency transcutaneous electrical nerve stimulation (TENS) on the viability of ischemic skin flaps in the rat: An amplitude study. Wound Rep Reg 2008;16:65-9.

4. Jones I, Johnson M. Transcutaneous electrical nerve stimulation (TENS). Continuing education in anaesthesia. Crit Care Pain 2009;9:130-5.

5. Chen C, Johnson MI. A comparison of transcutaneous electrical nerve stimulation (TENS) at 3 and 80 pulses per second on coldpressor pain in healthy human participants. Clin Physiol Funct Imaging 2010;30:260-8.

6. Liebano RE, Rakel B, Vance CG, Walsh DM, Sluka KA. An investigation of the development of analgesic tolerance to TENS in humans. Pain 2011;152:335-42.

7. Chen C, Johnson MI, McDonough S, Cramp F. The effect of transcutaneous electrical nerve stimulation on local and distal cutaneous blood flow following a prolonged heat stimulus in healthy subjects. Clin Physiol Funct Imaging 2007;27:154-61.

8. DeSantana JM, Walsh DM, Vance C, Rakel BA, Sluka KA. Effectiveness of transcutaneous electrical nerve stimulation for treatment of hyperalgesia and pain. Curr Rheumatol Rep 2008;10:492-9.

9. Kjartansson J, Lundeberg T, Samuelson UE, Dalsgaard J. Transcutaneous electrical nerve stimulation (TENS) increases survival of ischemic musculocutaneous flaps. Acta Physiol Scand 1988;134:95-9.

10. Kjartansson J, Lundeberg T, Samuelson UE, Dalsgaard J, Hedén P. Calcitonin gene-related peptide (CGRP) and transcutaneous electrical nerve stimulation (TENS) increase cutaneous blood flow in a musculocutaneous flap in the rat. Acta Physiol Scand 1988;134:89-94.

11. Kjartansson J, Lundeberg T, Körlof B. Transcutaneous electrical nerve stimulation (TENS) in ischemic tissue. Plast Reconstr Surg 1988;81:813-5.

12. Johnson MI. Transcutaneous Electrical Nerve Stimulation (TENS). In: Watson T. Electrotherapy: Evidence-Based Practice, 12th edn. Toronto: Elsevier, 2008.

13. Melzack R, Wall P. Pain mechanisms: A new theory. Science 1965;150:971-9.

14. Scudds RJ, Helewa A, Scudds RA. The effects of transcutaneous electrical nerve stimulation on skin temperature in assintomatic subjects. Phys Ther 1995;75:622-8.

15. Atalay C, Yilmaz KB. The effect of transcutaneous electrical nerve stimulation on postmastectomy skin flap necrosis. Breast Cancer Res Treat 2009;117:611-4.

16. Sherry JE, Oehrlein KM, Hegge KS, Morgan BJ. Effect of burstmode transcutaneous electrical nerve stimulation on peripheral vascular resistance. Phys Ther 2001;81:1183-91.

17. Ferreira LM, Hochman B, Barbosa MVJ. Modelos experimentais em pesquisa. Acta Cir Bras 2005;20(Suppl);2:28-34.

18. Hochman B, Nahas FX, Oliveira Filho RS, Ferreira LM. Desenhos de pesquisa. Acta Cir Bras 2005;20(Suppl);2:2-9.

19. Marques MA, Peccin MS. Pesquisa em fisioterapia: A prática baseada em evidências e modelos de estudos. Fisioter Pesq 2005;11:43-8.

20. Lundeberg T, Kjartansson J, Samuelsson U. Effect of electrical nerve stimulation on healing of ischemic skin flaps. Lancet 1988;24:712-4.

21. Kjartansson J, Lundeberg T. Effects of electrical nerve stimulation (ENS) in ischemic tissue. Scand J Plast Reconstr Hand Surg 1990;24:129-34.

22. Niina Y, Ikeda K, Iwa M, Sakita M. Effects of electroacupuncture and transcutaneous electrical nerve stimulation on survival of musculocutaneous flap in rats. Am J Chin Med 1997;25:273-80.

23. Khalil Z, Merhi M. Effects of aging on neurogenic vasodilator responses evoked by transcutaneous electrical nerve stimulation: Relevance to wound healing. J Gerontol Biol Sci 2000;55A:B257-63.

24. Khalil Z, Merhi M, Livett BG. Differential involvement of conotoxin-sensitive mechanisms in neurogenic vasodilatation responses: Effects of age. J Gerontol Biol Sci Med Sci 2001;56:B356-63.

25. Liebano RE, Ferreira LM, Sabino Neto M. The effect of the transcutaneous electrical nerve stimulation on the viability of random skin flaps in rats. Can J Plast Surg 2002;10:151-4. 
26. Atalay C, Koçkaya EA, Cetin B, Kismet K, Akay MT. Efficacy of topical nitroglycerin and transcutaneous electrical nerve stimulation on survival of random-pattern skin flaps in rats. Scand J Plast Reconstr Surg Hand Surg 2003;37:10-13.

27. Liebano RE, Abla LEF, Ferreira LM. Effect of high frequency transcutaneous electrical nerve stimulation on viability of random skin flap in rats. Acta Cir Bras 2006;21:133-8.

28. Russo CRA, Leite MT, Gomes HC, Ferreira LM. Transcutaneous electrical nerve stimulation in viability of a random skin flap in nicotine-treated rats. Ann Plast Surg 2006;57:670-2.

29. Kaada B. Vasodilation induced by transcutaneous nerve stimulation in peripheral ischemia (Raynaud's phenomenon and diabetic polyneuropathy). Eur Heart J 1982;3:303-14.

30. Biedebach M. Accelerated healing of skin ulcers by electrical stimulation and intracellular physiological mechanisms involved. Acupunct Electrother Res 1989;14:43-60.

31. Finsen L, Persen L, Løvlien M, et al. Transcutaneous electrical nerve stimulation after major amputation. J Bone Joint Surg Br 1988;70-B:109-12.

32. Kaada B. Emru M. Promoted healing of leprous ulcers by transcutaneous nerve stimulation. Acupunct Electrother Res 1988;13:165-76.

33. Lundeberg T, Eriksson S, Malm M. Electrical nerve stimulation improves healing of diabetic ulcers. Ann Plast Surg 1992;29:328-31.

34. Debreceni L, Gyulai M, Debreceni A, Szabó K. Results of transcutaneous electrical stimulation (TES) in cure of lower extremity arterial disease. Angiology 1995;46:613-8.

35. Baker LL, Chambers R, Demuth SK, Villar F. Effects of electrical stimulation on wound healing in patients with diabetic ulcers. Diabetes Care 1997;20:405-12

36. Baker LL, Rubayi S, Villar F, Demuth SK. Effect of electrical stimulation waveform on healing of ulcers in human beings with spinal cord injury. Wound Rep Reg 1996;4:21-8.

37. Forst T, Pfützner A, Bauersachs R, et al. Comparison of the microvascular response to transcutaneous electrical nerve stimulation and postocclusive ischemia in the diabetic foot. J Diabetes Complications 1997;11:291-7.

38. Wikström OS, Svedman P, Henry S, Tanweer AS. Effect of transcutaneous nerve stimulation on microcirculation in intact skin and blister wounds in healthy volunteers. Scand J Plast Reconstr Hand Surg 1999;33:195-201.

39. Cosmo P, Svensson H, Bornmyr S, Wikström S. Effects of transcutaneous nerve stimulation on the microcirculation in chronic leg ulcers. Scand J Plast Reconstr Hand Surg 2000;34:61-4.

40. Karba R, Benko H, Savrin R, Vodovnik L. Combination of occlusive dressings and electrical stimulation in pressure ulcer treatment. Med Sci Res 1995;23:671-3.

41. Kaada B, Olsen E, Eielsen O. In search of mediators of skin vasodilation induced by transcutaneous nerve stimulation:
III. Increase in plasma VIP in normal subjects and in Raynaud's disease. Gen Pharmacol 1984;15:107-13.

42. Kaada B, Helle KB. In search of mediators of skin vasodilation induced by transcutaneous nerve stimulation: IV. In vitro bioassay of the vasoinhibitory activity of sera from patients suffering from peripheral ischemia. Gen Pharmacol 1984;15:115-22.

43. Abram SE, Asiddao CB, Reynolds AC. Increased skin temperature during transcutaneous electrical stimulation. Anesth Analg 1980;59:22-5.

44. Nolan MF, Hartsfield JK, Witters DM, Wason PJ. Failure of transcutaneous electrical nerve stimulation in the conventional and burst modes to alter digital skin temperature. Arch Phys Med Rehab 1993;74:182-7.

45. Cramp AFL, Gilsenan C, Lowe AS, Walsh DM. The effect of high- and low-frequency transcutaneous electrical nerve stimulation upon cutaneous blood flow and skin temperature in healthy subjects. Clin Physiol 2000;20:150-7.

46. Cramp AF, Noble JG, Lowe AS, Walsh DM. Transcutaneous electrical nerve stimulation (TENS): The effect of electrode placement upon cutaneous blood flow and skin temperature. Acupunct Electrother Res 2001;26:25-37.

47. Cramp FL, McCullough GR, Lowe AS, Walsh DM. Transcutaneous electric nerve stimulation: The effect of intensity on local and distal cutaneous blood flow and skin temperature in healthy subjects. Arch Phys Med Rehabil 2002;83:5-9.

48. Simpson KH, Jason Ward J. A Randomized, double-blind, crossover study of the use of transcutaneous spinal electroanalgesia in patients with pain from chronic critical limb ischemia. J Pain Symptom Manage 2004;28:511-6.

49. Burssens P, Forsyth R, Steyaert A, Van Ovost E, Praet M, Verdonk R. Influence of burst TENS stimulation on the healing of Achilles tendon suture in man. Acta Orthop Belg 2003;69:528-32.

50. Jenbeck J, Daslgaard CJ. Calcitonin gene-related peptide treatment of flaps with compromised circulation in humans. Plast Reconstr Surg 1993;91:236-44.

51. Burssens P, Forsyth R, Steyaert A, Van Ovost E, Praet M, Verdonk R. Influence of burst TENS stimulation on collagen formation after Achilles tendon suture in man. A histological evaluation with Movat's pentachrome stain. Acta Orthop Belg 2005;71:342-6.

52. Cetti R, Christensen SE, Ejsted R, Jensen NM, Jorgensen U. Operative versus nonoperative treatment of Achilles tendon rupture. A prospective randomized study and review of the literature. Am J Sports Med 1993;21:791-9.

53. Stehno-Bittel L, Reddy GK, Gum S, Enwemeka CS. Biochemistry and biomechanics of healing tendon: Part I. Effects of rigid plaster casts and functional casts. Med Sci Sports Exerc 1998;30:788-93. 